\title{
ASSET VALUATION STANDARDS: A FUNCTIONAL-INSTITUTIONAL APPROACH
}

\author{
Tomáš Krabec*
}

\begin{abstract}
:
The article focuses on the elaboration and research of the real nature of standards of value. The methodology chosen for this paper is mainly based on the late institutional economics and European theories of the economic and legal order, such as the German ordoliberalism. It is argued that standards (International Valuation Standards, European Valuation Standards, IDW S 1 etc.) are not determined by the stage of development of economic theory, but rather by valuation "best practices". The standards of value, which are normatively defined, first enable us to connect the valuation and the valuation purpose. The value standard or the contained value basis establishes the connection between the value and the valuation purpose, and make the estimated value relevant, or subject to the valuation purpose. Further, the purpose of the standards as a set of rules is examined, and the entities involved in the formulation of the standards and its influence are closely connected. There were identified three driving forces shaping the current scope and status of both international and national valuation standards: firstly, the state and legislation (hard and soft law), secondly, science providing a methodological background, and lastly, joint interest groups, such as appraisers and appraisers' associations who are generally responsible for the final versions of the standards. Since Czech commercial law does not precisely address all possible market transactions and applicable standards of value, it is argued that the International Valuation Standards can and should also be applied in the Czech Republic, since their purpose would show its effect in the Czech Republic, too. Other inspiration for business valuation can be found in the German IDW S 1 standard.
\end{abstract}

Keywords: valuation standards, market value

JEL Classification: G 39

\section{Introduction}

In the economic process, it often happens that we need to know the value of assets (a business, part of a business, intangible assets, movables and immovables, etc.). As it is impossible to determine the value of a transaction "objectively", i.e. clearly and regardless of the valuation purpose and participants in a real or hypothetical transaction, it is important to follow certain valuation rules. The valuation is always based on the legal and, more broadly, institutional set of rules, within which economic activities and

* University of Economics, Prague, nám. W. Churchilla 4, 13067 Prague 3, Czech Republic (krabec@ yahoo.com).

This paper was written with the support of the Research Project of the Faculty of Finance and Accounting of University of Economics within the framework of an institucional support No. IP100040. 
property transactions are carried out. However, this framework provides a wide range of possible ways of conducting these property transactions, and thus makes appraiser's task more difficult, as they have to calculate the value applicable to the purpose assigned by the entity ordering the valuation. The valuation rules or standards supplement the legal order and thus lead to a higher level of structuredness of valuation problems. Problems, which have not been solved within the economic theory so far, and which, we suppose, cannot be solved due to their intricacy and information complexity (calculation of generally applicable equilibrium market prices, assumptions with respect to characteristics of individual market makers and their preferences, etc.), can be structured only in this form of normative regulation. In this paper, attention will be drawn to multiple assets and the principles of their valuation.

As there is no established and generally respected standardisation of business valuation in Central and Eastern Europe, it leads to terminological chaos in practice, and often to an impossibility to interpret results clearly. The present situation causes significant practical difficulties, as a valuer (an appraiser or certified expert) estimates the "market value of a business" without defining this value category in any way, and enabling the valuation user to interpret the result, or when the market value is interpreted according to the International Valuation Standards, which is defined by the appraiser by copying a complex sentence containing the definition, but generously overlooking the remaining dozens of pages of the International Valuation Standards, which require that all definition conditions of the asset market quality specified in the standard are met, and historical equilibrium prices are available.

The primary goal of the explanation of the essence of the standardisation and origination and purpose of valuation standards contained in this text is to demythologise the perception of the standards as a "product of the economic theory", and also to moderate the ambitious expectations of laymen with respect to the quality and applicability of results of practical valuation experts' reports. Authors of the standards, whose co-operation creates the present form of codification of valuation "best practice" rules, will be discussed in detail. In the area of the business economics theory, valuation rules understood within the meaning of codification of generally recognised principles have been a topic of interest since the 1960s. The fundamental literature forming the theoretical basis and, in some cases, an important clue for practical standardisation, includes mainly the work of Moxter (1990), who introduced the concept of proper business valuation principles (Grundsätze ordnungsmäßiger Unternehmensbewertung) in valuation theory, which is also the title of his book published in 1976, and later republished several times, and the work of Matschke and Brösel (2007), and Hering (2006). In practice, the valuation process is regulated in various ways and by means of various types of rules. In this text, attention will be primarily focused on the situation in the Czech Republic, where the valuation of multiple assets is regulated by the Asset Valuation Act, which applies to a very limited range of cases, and also by non-binding supranational rules, i.e. especially by the International Valuation Standards (IVS), European Valuation Standards (EVS); German professional business valuation standards IDW S 1 are an inspiring 
source, too. The regulation is not and cannot be exhaustive; it cannot cover all possible transactions, the value of which must be appraised. Therefore, the standards must keep their non-mandatory character and flexibility, enabling appraisers to use their knowledge of the related economic practice and economic and/or business economics theory in deciding how they will handle the particular assignment of a valuation report.

\section{The Essence of Standardisation as a Need for the Reduction of Complexity}

There are several important characteristics, which are common for all asset valuation standards. Primarily, they are codified rules of conduct as they developed within the meaning of "best practice" according to responses to user needs and, in particular, as they succeeded as a result of trials and errors within real transactions. On a general level, Hayek comments on this as follows: "The rules of conduct then only serve for avoiding conflicts and facilitating the co-operation by eliminating some sources of doubts. However, since they are aimed at enabling each individual to act according to his own plans and decisions, they cannot eliminate uncertainty entirely" (1994, p. 168), and even, in relation to exchange, he adds that the rules: "cannot guarantee, for example, that [an individual] is able to sell what they offer or buy what they need at an expected price" (ibid). Mathematic economists have a similar attitude to the importance of the rules and their economic and generalised biological efficiency: "As only the most capable survive, the type of man who does not live in the world of regularities will be eliminated ... Therefore, regularities are a permanent topic of interest of the science" (Frisch, in: Jonáš, 1994, p. 43). In formulating proper business valuation principles, Moxter (quotation according to Matschke, Brösel, 2007, p. 734) sees his contribution "only" in the fact that he transforms the existing principles into a conditional form, i.e. what the evaluation "should be like".

Valuation standardisation cannot be deemed a consciously and purposefully created rational construct or "product" of continuously improving economic theory. Valuation standards result from the evolution of rules; respond to regularly repeating the practical needs of participants in economic mechanism. It is the codification of principles, procedures, and rules which have proved to be effective, supported by practical experience. The International Valuation Standards are the most complex "subcode", which has grown on an evolutionary basis; a comprehensive set of codified rules within general regulations of business law and, to a certain extent, also competition, tax, and criminal law. They include rules defined primarily in order to reduce the uncertainty in deciding and planning by market participants. Of course, this is not to say that the codification or the rules are perfect. Development requires continuous reformulation and modification of established rules. In this sense, it is a continuous activity. Only one thing can be said with confidence: the valuation standardisation rules are not and cannot be perfect or exhaustive. In the conditions of the information-complex market mechanism, no human being is able to formulate objective and verifiable criteria of correctness and the applicability of rules. 
The meaningfulness and desirability of standardisation has been approaching because, for certain reasons, it is advantageous to follow codified and generally known rules. The valuation user must be able to interpret valuation conclusions clearly. The fact that an appraiser has followed a certain set of rules enables this, by giving a clear interpretation of contents to the result. Unfortunately, this fact is often partially misused. There is a strong information asymmetry between the valuation author and valuation user. If the valuation author refers to rules recognised worldwide, it does not mean at all that the valuation meets the quality parameters which the ordering party expected, either implicitly or explicitly. Procedures and conclusions can be verifiable and repeatable, but not objectively correct.

The standards serve as a subordinate non-binding regulation. They do not necessarily apply to all market transactions. However, they contribute to market quality to a considerable extent, especially by making the expectations of market subjects - ordering parties and users of valuation reports - more stable, mainly in the sense of normative definition of the basic assumptions and definition of conditions of validity of the calculated value. In the following text, effects following on from the existence and application of the standards for users of valuation reports drawn within the codified rules will be analysed in detail.

\section{The Purpose of Valuation Standardisation Rules}

Valuation principles, which have been mainly formulated within scientific and academic discussion, serve as the basis of formalised appraisal rules (or rather valuation rules). Czech professional literature understands the concept of "appraisal" much more broadly than either standards or English and German literature. In Czech, oceňováni refers to activities, which, within the established terminology, cover both appraisal (oceňování, Preisfindung), and valuation (ohodnocování, Bewertung). The terminology is discussed in detail by Krabec (2007, 2008, 2009). Matschke and Brösel (2007, p. 719 et seq.) who define the principles of business valuation (Grundsätze der Unternehmensbewertung) as: "the system of mutually - if possible - non-contradictory standards for the management of the business valuation process, i.e. procedure and deduction of a result."

The basic contents and purpose of the system of valuation standards can be summed up in the following points:

- They should contribute to the reduction of complexity of the economic and social mechanism and contribute to the reduction of uncertainty and transaction costs in creating economic plans.

- They define the terminology to be applied within appraisal reports, and they partially extend to accounting terminology by specifying certain accounting categories of value.

- They define conditions for valuation in accordance with a selected category of estimated value (abstraction), i.e. they clarify the relationship between the valuation purpose and relevance of the calculated value, primarily by creating model situations 
via the category of value within the information-complex real world, which are determined by certain assumptions as to the valuation object and subject, but the existence of a standard enables the users of the valuation report to interpret the result clearly, and also to repeat or verify the deduction, which means that the calculation or analytic procedure is "correct" in accordance with the definition contained in the standard, and therefore also with a standard as a consensually recognised rule, without the appraiser trying to e.g. estimate the "objective", "theoretically correct", or "generally applicable" market value (see the theoretical explanation and arguments in Krabec, 2008); these are also relatively complex phenomena of the theory of order, which are further elaborated in the appraisal discipline within the functional concept of the business valuation (see Moxter, 1990, Gorny, 2002, Helbling, 1998, Matschke, Brösel, 2007). The essence of this approach lies in the refusal of one generally correct and generally applicable value. The value is always bound by the valuation purpose; an appraiser also performs the role of a certain function, which he estimates the value for (mediating, arguing, arbitrating). However, abstraction and generalisation also occur in this case too, thanks to standardisation, but the conditionality of the applicability of the result bound by the purpose is preserved, and the possibility to verify the result, thanks to the reduction of complexity of actual market conditions, is preserved, too.

- They provide the users of appraisal reports with higher certainty that the quality of the solution is high, and that the solution is correct in a sense, if it is based on recognised rules, the appraiser being responsible for the preparation, in accordance with the standards as a whole; if the appraiser claims compliance with them, the standards contribute to the performance of the informative function (Matschke, Brösel, 2007), or analogically, the function of supporting communication within the team of appraisers, who use the standard as a reference for facilitating the working process and communication (Pooten, 1999). This is why it is, among other things, extremely difficult to try to find an "objective market value" or similar indefinite categories of value, which have not been defined so far, the interpretation of which is misleading, and the application of the result is therefore limited. The quality and "correctness" should again be deemed relative terms valid within the standards, because there is no invariant correctness criterion; in the case of the principles of a functional business valuation, Matschke and Brösel 2007 talk about a triple protective function (ternärer Schutzzweck), where, firstly, interests of appraisers are protected, because professional malpractice is supressed (Kunstfehler, see Moxter, 1990); secondly, interests of owners and, thirdly, interests of the management, who are responsible for their activities in respect of the owners, and are obligated to act with due diligence and professional care, are protected.

- Compared to accounting standards, asset valuation standards have much more of a non-mandatory character, which is mainly caused by a lower frequency of standardised activities when compared with accounting; the appraisal is then a compromise between the limit values of market parties (market makers or valuation 
subjects) provided that the complexity of the real world has been reasonably reduced (see Moxter, 1990).

- Even if the expertise and probability of the solution required by the standards were preserved, the appraisal of the market value category could not be deemed an objective and indisputable estimation of an equilibrium market price; Matschke and Brösel (2007) nor even define a separate purpose of the standards, which is the moderation of expectations by lay users (Erwartungsminderungszweck) regarding the possible estimation of a relevant value category and its informative value.

\section{Valuation Standardisation Sources}

The experience has proved that it is impossible and undesirable to leave the valuation process without restraint, subject to general business law regulations. Valuation standardisation is just one of many areas where the economic process is controlled by regulatory principles and rules. For example, competition rules also supplement and establish norms for the decision-making process of economic subjects (for more information about the theory and functions of the economic system, see Eucken, 1990). Users' requirements for valuation quality are broader. The standards perform various functions in various countries. Primarily, it is important to know the statutory regimentation of valuation as such, and also the regulation of the appraiser's activities, i.e. who appraises, when they appraise, and what rules are applied. Following the particular regulation, subjects formulating and/or codifying the valuation standards are differentiated. In this sense, three main sources of valuation standardisation can be defined: the state, the science (primarily in the sense of economic theory and business valuation theory), and professional interest organisations.

a) The state (law, legislation, and practice of the courts)

It contributes mainly in the area of cultivation and evolution of the legal environment. The standards (or their users in a particular case) must respond to the development of legislation, and comply with it. In some cases, they directly reflect court decisions and draw parameters of appraisals, which acquire arbitration contents specified by the court decision. Next, it is the regulation of the appraisal process which directly has the form of a statute, or of subordinate binding legal regulations. The relationship between the statutory regulation and professional standards can be bilateral, and it depends on the influence of interest groups on the legislative process (see below); however, the fact that the statutory regulation of valuation and regulation within professional standards has a different purpose is important.

b) The science

The science, in the sense of the broad notion of economic theory and business valuation theory (Unternehmensbewertungstheorie), is the second source of standardisation. The economic theory influences the valuation process, mainly from a methodological point of view. As the theoretical models and methods, their informative value, and application 
develop, the standards remain an open and evolving set of rules. In addition to economic theory, which is primarily aimed at explaining and expressing the general principles of economic phenomena (in this context Debreu, 1959, Fama, 1977, Kruschwitz, Löffler, 2006, Lintner, 1965, Mossin, 1966, Markowitz, 1952, Modigliani, Miller, 1958, 1963), there is a parallel discipline which cannot be considered identical with respect to the contents and purposes. It is a theory of appraising business enterprises and multiple assets. The valuation theory can therefore be characterised as a subset of various forms of a widely comprehended generalising economic theory, dealing with value aspects of property transactions with multiple assets, and with the calculation of their value in connection with the valuation purpose.

The early beginnings of the valuation theory date back to the $19^{\text {th }}$ century, mainly to the German speaking area. This discipline underwent significant development in the twentieth century, when the concept of the discipline as such (objective, subjective, the so-called market and functional concept - see the exhaustive list in Matschke, Brösel, 2007 and Born, 2003) had become a topic of interest, as with the methodology. Business valuation concepts draw their methodological grounds from economic theory, and provide them with the interpretation contents in connection with the assignment, and according to the purpose of a particular valuation task. This is a significant difference to the generalising theory.

There are opinions that the "standardisation of valuation is a product of economic theory", or that "the more advanced the development of economic theory is, the better the practical valuation of assets and its standardisation will be" (see Mařík, Krabec, 2006). The essence of the market mechanism indicates that it is impossible to determine equilibrium market prices. It is a detrimental overestimation of the abilities of appraisers and appraisal methods, as well as a false impression of knowledge (see Hayek, 1995). In this sense, misunderstanding occurs on the part of users of valuation reports, who believe that financial experts are really able to determine the "objective" or "correct" value; some appraisers, especially those influenced by Anglo-Saxon tradition, ambitiously refer to the result obtained by the income based method as the market value of a business, or even as the market value according to the International Valuation Standards. The fact that escapes the notice of many laymen at first sight is that no one has specified the market, whether it is the actual market of business enterprises, or an abstract model of a neoclassical capital market, which is very distant from reality where the appraiser tries to calculate the amount for which the business could hypothetically be sold "as if" it were the subject-matter of a transaction in a perfect capital market, is generously overlooked. Of course, consequences are important for the informative value of the amount calculated in this way. The income based value only equals the market value (equilibrium market price) in a perfect capital market. Moreover, the opportunity to create "the impression of objectiveness", which is so attractive for lay users (lawyers, judges, public authorities), is worse (see FischerWinkelmann, 2003 and the principle of "moderation of expectations" above).

In the area of business valuation theory, several approaches and systematisations of the "principles of due valuations" have formed, which are more or less reflected 
in actual valuation standards. The first, and probably the best known, systematisation was introduced by Moxter (1976, here quoted according to 1990); a factually more extensive theoretical concept is contained in the work of Pooten 1999, who, unlike Moxter, considers the argumentative function, in addition to the arbitrating and mediating functions.

\section{c) Professional and interest organisations}

Professional or interest organisations are important because they both create standards in their final form, i.e. they draw from other sources, and they add specific needs to them so that the codification always reflects the current economic reality and extensive business practice. Also, it is important to realize that the definition of interest groups indicates that their goal is to maximise the benefits of their members. This issue goes far beyond the focus of this paper (see the wide scope of ordoliberal and new institutional economy in Eucken, 1990, Olson, 1982). It is obvious that the final form of standards will be decided by the composition of members of the organisation, as well as the form of an approval procedure. Greatest attention is paid to the standardisation of valuation of real estate, which is a consequence of the size and liquidity of real estate markets. The business valuation is explicitly covered by the IDW S 1 standard and IVS standards.

\section{National and Supranational Regulation of Valuation}

Standardisation also responds to developing transactions carried out in an international environment. The question is, to what extent the autonomy of the national regulation of valuation can be preserved. The legal order of a relevant country and its compatibility, especially in the area of commercial and tax law and the regulation of the accounting process, will create conditions for the possible harmonisation of valuation standards. The rules of global standardisation are characterised by their endogenous, spontaneous character. Particular targets, purposes, and intentions, which the standardisation process should lead to, cannot be identified. A target is defined within general assumptions on an abstract basis. The rules serve users as the adaptation to complexity and intricacy of the economic mechanism. The fact that the rules apply to each user of the standards equally is extremely important. This also enables us to use some of the unified sets of standards in an environment with various legislative traditions, because the higher level of generality still guarantees the unambiguity of the interpretation of a result, and, at the same time, the appraiser can consider local specifics, while, of course, it is necessary to state all modifications and procedures beyond the scope of the regulation codified by the standard (which is available to each user) properly, and comment on them in the valuation report.

In the Czech Republic, the business valuation process is regulated by law and applicable regulations, which are binding only for particular purposes, defined directly by law. Provisions of Section 1 of Act no. 151/1997 Sb., the Asset Valuation Act, say that: "The Act regulates the ways of appraising things, rights, and other asset values (hereinafter "assets") and services for the purposes defined by special regulations. If these regulations refer to any price or special regulations for appraising assets or services for any purpose 
other than sale, this Act shall be understood as that regulation. The Act also applies for the purposes defined by special regulations specified in Part 4 to 9 of the Act, and also if a competent authority ordains so within its powers, or if the parties agree so."

The most important regulation for valuation for the purposes of standard business transactions regimented by commercial law is the regulation of the International Valuation Standards (see Mařík et al., 2011). In some countries of Central and Eastern Europe (Slovenia, Slovakia), IVS are applied directly as national valuation standards (no official Czech translations has been made so far). In addition, national and supranational regulation is interconnected by the fact that IVS are formulated by representatives of national organisations of professional appraisers within IVSC (International Valuation Standards Committee, since 2008 known as International Valuation Standards Council).

\section{Conclusion}

Valuation is based on two types of orders - spontaneous market transactions, as well as consciously created statutory regulation. While changes in statutory rules, statutory valuation terminology, or purpose of the legislation can be easily made, conscious transformation of evolved rules affecting principles is not so easily accomplishable. It requires parallel changes in other sources of standardisation, scientific grounds in the field of economic theory, specifically the valuation theory, and their acceptance in practice, and finally formal standardisation (codification).

To appraise (valuate) business enterprises in the Czech Republic, value categories defined within the International Valuation Standards can be applied. However, it is necessary to define clearly the purpose of the valuation, and select the corresponding value category according to that. It is also important to avoid a non-critical general approach, where the result is called a "market value", while the appraiser does not deal with its definition and does not examine the conditions of its existence in appraising unique multiple assets. The existence and application of the standards would pay mostly here, because they provide appraisers with a rich source of time-proven rules, and protect them from needless exposure to the risk of invalidity of a calculated amount for the relevant purpose of the appraisal. The user interprets the results correctly, and the appraiser is responsible for the correct selection of a value category, and for the correct selection and way of use of methods of its estimation.

The above mentioned role of the standards protecting appraisers from invalid interpretations of the results applies also for the users of those results. Since there is an obvious information asymmetry between appraisers and users of the valuation reports the knowledge of standards and its correct and thorough application is primarily by the appraisal. Therefore, correctly applied valuation standards fulfill a systematically important role in the market economy and its functioning. The importance of correct interpretation of the valuation outcomes can also be seen in the partial prevention of future financial crises. In particular, the convergence of valuation and financial reporting standards will be of great importance. The professional responsibility of the appraisals together with the sources of standardization, as defined in this article, will play an important role in this development. 


\section{References}

Born, K. (2003), Unternehmensanalyse und Unternehmensbewertung. 2nd Ed. Stuttgart: SchäfferPoeschel Verlag.

Debreu, G. (1959), Theory of Value. London: New Heaven.

Eucken, W. (1990), Grundsätze der Wirtschaftspolitik. 6th Ed. Tübingen: J. C. B. Mohr.

Fama, E. F. (1977), "Risk-Adjusted Discount Rates and Capital Budgeting under Uncertainty." Journal of Financial Economics, Vol. 5, No. 1, pp. 3-24.

Fischer-Winkelmann, W. F. (2003), MC - Management-Consulting \& Controlling. Hamburg: Kovac Verlag.

Gorny, C. (2002), Unternehmensbewertung in Verhandlungsprozessen. Wiesbaden: Deutscher Universitäts-Verlag.

Hayek, F. A. (1995), Kontrarevoluce vědy. Praha: Liberální institut.

Hayek, F. A. (1994), Právo, zákonodárství a svoboda. Praha: Academia.

Helbling, C. (1998), Unternehmensbewertung und Steuern. 9th Ed. Düsseldorf: IDW-Verlag.

Hering, T. (2006), Unternehmensbewertung. 2nd Ed. München, Wien: Oldenbourg.

IDW (2007), Standard IDW S 1: Grundsätze zur Durchführung von Unternehmensbewertungen. Düsseldorf: IDW-Verlag.

IVS (2007), International Valuation Standards. London: IVSC.

IVS (2011), International Valuation Standards. London: IVSC.

Jonáš, J. et al. (1994), Oslava ekonomie. Prague: Academia.

Krabec, T. (2006), Teoretická východiska soutěžní politiky. Prague: Národohospodářský ústav Josefa Hlávky.

Krabec, T. (2007), "Operabilita pojmu tržní hodnoty v intencích standardizace oceňování." Politická ekonomie, Year LV, No. 2, pp. 263-274.

Krabec, T. (2008), "Několik poznámek k terminologii ohodnocování aktiv." Oceňování, Vol. 1, No. 3-4, pp. $47-54$.

Krabec, T. (2009), Oceňování podniku a standardy hodnoty. Prague: Grada.

Kruschwitz, L., Löffler, C. (2006), Discounted Cash Flow: A Theory of the Valuation of Firms. Chichester: John Wiley and Sons.

Lintner, J. (1965), "The Valuation of Risk Assets and the Selection of Risky Investments in Stock Portfolios and Capital Budgets." The Review of Economics and Statistics, Vol. 47, No. 1, pp. 13-37.

Markowitz, H. (1952), "Portfolio Selection." Journal of Finance, Vol. 7, No. 1, pp. 77-91.

Mařík, M., Krabec, T. (2006), “K objektivnosti tržní hodnoty.” Acta Economica Pragensia. pp. 9-22.

Mařík, M. et al. (2011), Metody oceňování podniku. 3rd Ed. Prague: Ekopress.

Matschke, M. J., Brösel, G. (2007), Unternehmensbewertung. 3rd Ed. Wiesbaden: Gabler.

Modigliani, F., Miller, M. H. (1958), "The Cost of Capital, Corporation Finance and the Theory of Investment." The American Economic Review, Vol. 48, No. 3, pp. 261-297.

Modigliani, F., Miller, M. H. (1963), "Corporate Income Taxes and the Cost of Capital: A Correction." The American Economic Review, Vol. 53, No. 3, pp. 433-443.

Mossin, J. (1966), "Equilibrium in a Capital Asset Market." Econometrica, Vol. 34, No. 4, pp. 768-783.

Moxter A. (1990), Grundsätze ordnungsmäßiger Unternehmensbewertung. 2nd Ed. Wiesbaden.

Olson, M. (1982), The Rise and Decline of Nations: Economic Growth, Stagflation, and Social Rigidities. Yale University Press.

Pooten, H. (1999), Grundsätze Ordnungsmäßiger Unternehmensbewertung. Büren. 